\title{
Ecology and utilization of salt-tolerant plants in the river basins of Central Asia
}

\author{
*Niels Thevs, **Stefan Zerbe, ***Walter Wucherer, *Allan Buras, *Bo Tang
}

\author{
* Institute of Botany and Landscape Ecology, Greifswald University, \\ Grimmer Strasse 88, 17487 Greifswald, Germany \\ e-mail: thevs@uni-greifswald.de \\ ** Faculty of Science and Technology, Free University of Bozen / Bolzano, \\ Universitätsplatz 1, Bozen / Bolzano, Italy
}

*** Michael-Succow-Foundation for the Conservation of Nature, Grimmer Strasse 88, 17487 Greifswald, Germany

Summary. In Central Asia soil salinization is a wide-spread concern. Biomass harvested from the moderate salt-tolerant species Haloxylon aphyllum and Apocynum pictum can be used as fodder as well as for textile fibers and medicinal purposes, respectively. These plants offer opportunities to generate income from saline soils.

Key words: Haloxylon, Apocynum, sustainable land use, biomass.

\section{Introduction}

Most river basins in Central Asia, like the Aral Sea Basin, the Ili Basin, and the Tarim Basin, are endorheic river basins. Therefore, salt lakes and saline soils with their associated salt-tolerant vegetation are a natural component of these river ecosystems. Starting with the 1950ties, the area under irrigation along the rivers in Central Asia, like Amu Darya, Syr Darya, Ili, Tarim, was massively increased. Today, the major crop grown along those rivers is cotton (Gossypium sp.). The irrigation seriously aggravated the soil salinization problems in Central Asian river basins so that agriculture had to be given up on large areas (Giese et al. 2004). Therefore, research about the utilization of salt-tolerant plants is of crucial importance, in order to provide economic benefit for the people whose fields are affected by soil salinization.

We propose that Haloxylon aphyllum and Apocynum species, as salt-tolerant native plants of the riparian vegetation, have a great potential for utilization. H. aphyllum can be used as fodder, energy source, and as biomass or carbon accumulating plant. $H$. aphyllum is distributed along current and former river courses in Kazakhstan, Uzbekistan, and Turkmenistan on non-saline to moderate saline soils. It is a phreatophyte, i.e. it takes up water from the groundwater (Rachkovskaya et al. 2003). Apocynum venetum and $A$. pictum (http://www.efloras.org) can be used as medicinal or fiber plant. A. venetum is distributed in Kazakhstan, Uzbekistan, Northern Xinjiang, and Inner Mongolia. A. pictum is distributed on more saline and dry sites compared to A. venetum and is the major Apocynum species in the Tarim Basin. It is a phreatophyte, too (Zhang et al. 2006).

We investigated the standing biomass of $H$. aphyllum and A. pictum on representative sites in Turkmenistan, Kazakhstan, and Xinjiang, China, respectively.

\section{Study area}

H. aphyllum was investigated in Repetek, Turkmenistan, in the Ili Delta, and in Zana Darya, Kazakhstan. A. pictum 
was investigated in Bachu, Shaya, and in Korla, i.e. the northern part of the Tarim Basin. The climate of all three study areas is arid and continental. The annual precipitation in Repetek, the Ili Delta, in Zhana Darya, and in the northern part of the Tarim Basin is 110, 140, 150, and 50 mm, respectively.

\section{Research methods}

At each site at least 3 representative sample points were chosen and $4 \mathrm{H}$. aphyllum shrubs were harvested. For the A. pictum measurement, at each site also at least 3 representative sample points were chosen. At each sample point 8 plots of $1 \mathrm{~m}^{2}$ each were harvested.

\section{Results}

The standing above-ground biomass of the $H$. aphyllum and $A$. pictum sites are given in Table 1 and Table 2, respectively.

\section{Discussion}

The above-ground stand biomasses of $H$. aphyllum in Repetek and in the Ili Delta are comparable to the standing above-ground biomass of the most productive Artemisia-Deserts listed by Thevs et al. (submitted to Forestery). Thus, $H$. aphyllum dominated desert vegetation must be counted to the most productive desert ecosystems. Further research steps should focus on the net primary production, in order to provide guidelines for sustainable utilization of the $H$. aphyllum biomass.

The stem biomass of $A$. pictum in Shaya is significantly higher than on the two other sites. In contrast to the site in Korla and Bachu, the site in Shaya receives occasional floods so that the groundwater is replenished occasionally. One third of the stem biomass of $A$. pictum yields fibers, which properties are comparable with cotton (Wang et al. 2007). The leafs can be readily marketed as tea. The above-ground parts of $A$. pictum re-grow out of the rhizome. Still, further research steps should focus on monitoring of biomass and rhizome nutrient changes under harvest, in order to avoid degradation of $A$. pictum stands through over-utilization.
Table 1. Standing above-ground biomass of Haloxylon aphyllum in Repetek, in the Ili Delta, and in Zhana Darya. In brackets: number of sample points, $a, b$ : different letters indicate significant differences at $\alpha \leq 0.05$

\begin{tabular}{|l|c|}
\hline \multicolumn{1}{|c|}{ Site } & Standing above-ground biomass $\left[\mathbf{t} \cdot \mathbf{h a}^{-\mathbf{1}} \mathbf{}\right.$ \\
\hline Repetek & $8.3 \pm 2.6(3) \mathrm{b}$ \\
\hline Ili Delta & $5.6 \pm 5(9) \mathrm{b}$ \\
\hline Zhana Darya & $0.7 \pm 0.3(3) \mathrm{a}$ \\
\hline
\end{tabular}

Table 2. Standing above-ground biomass of Apocynum pictum in Bachu, Shaya, and Korla: In brackets: number of sample points. a, b: different letters indicate significant differences at $\alpha \leq 0.05$

\begin{tabular}{|l|c|c|}
\hline Site & $\begin{array}{c}\text { Standing stem biomass } \\
{\left[\mathbf{k g} \cdot \mathbf{h a}^{-1} \text { ] }\right.}\end{array}$ & $\begin{array}{c}\text { Leaf biomass } \\
{\left[\mathbf{k g} \cdot \mathbf{h a}^{-1} \text { ] }\right.}\end{array}$ \\
\hline Bachu & $727 \pm 102(6) \mathrm{a}$ & $353 \pm 113(6) \mathrm{a}$ \\
\hline Shaya & $2433 \pm 834(3) \mathrm{b}$ & $777 \pm 365(3) \mathrm{a}$ \\
\hline Korla & $480 \pm 264(3) \mathrm{a}$ & $264 \pm 119(3) \mathrm{a}$ \\
\hline
\end{tabular}

\section{References}

Giese E., Sehring J. \& Trouchine A., 2004, Zwischenstaatliche Wassernutzungskonflikte in Zentralasien, Zentrum für Internationale Entwicklungs- und Umweltforschung / ZEU), Universität Giessen, Giessen.

Rachkovskaya E. I., Volkova E. A. \& Khramcov V. N., (eds.), 2003, Botanical Geography of Kazakhstan and Middle Asia, Sanct-Petersburg.

Thevs N., Buras A., Zerbe S., Kühnel E., Abdusalih N. \& Ovezberdyyeva A., Structure and wood biomass of near-natural floodplain forests along the Central Asian rivers Tarim and Amu Darya (submitted to Forestry).

Wang L., Han G. \& Zhang Y. M., 2007, Comparative study of composition, structure and properties of Apocynum venetum fibers under different pretreatments, Carbohydrate Polymers 69: 391-397.

Zhang W. M., Xiao Z. C., Gu G. P., Zhang G. L. \& Qian X. S., 2006, On the Resources Utilization of Apocynum and Its Classification, Chinese Wild Plant Resources 25: $15-19$. 